\title{
ROLE OF ISLAM IN MALAYSIA'S PUBLIC DIPLOMACY: ABDULLAH BADAWI ADMINISTRATIONS
}

\author{
Nur Fareha \\ IIUM Malaysia \\ farehazukri@gmail.com
}

\begin{abstract}
This paper investigates the role of Islam in Malaysia's as a reform on soft power tools under the leaderships of Malaysia's fifth Prime Minister, Tun Abdullah Badawi. The study emphasis the reform in policy making, philosophies and approaches of the premiers in developing an understanding of the importance of Islam's role in Malaysia's public diplomacy. The research also determines the influence of international events in the public diplomacy policies. The study takes a constructivist approach and includes faith diplomacy into the realm of public diplomacy. This study has achieved its objective of understanding Islamic public diplomacy in Malaysia's administration and should be useful for developing future policies of public diplomacy for domestic and international consumption. It is an interesting reflection of this study that the common perception that Abdullah's public diplomacy was not successful is incorrect; this perception is founded on the labelling that Abdullah's version carried, which is because Abdullah, true to his character and personality, embraced and enriched previous premiership Islamization principles, without wanting to change them. Though there are arguments as discussed that Islam Hadhari declined, it only declined in the domestic context. In the international arena it appealed to a much wider audience.
\end{abstract}

Keywords : Role Of Islam; Malaysia's Public Diplomacy; Abdullah Badawi Administrations.

\section{A. INTRODUCTION}

As the world grows more complex and an increasing number of agencies, organizations, and people within countries have developed an interest in what happens in the domestic and international levels, leaders in democratic political systems face several options that will affect the policy choices of the state both at the domestic and international levels. In order to secure the survival and success of these policies at the domestic level, nations need to strengthen their international relations, and foreign policies are the major tools for this.

The element of Islam in Malaysia's administration is not new. From the time of independence of Malaysia, Islam has been a major component as the official religion of 
Malaysia followed by most of its population. Tunku Abdul Rahman, the first prime minister of Malaysia after independence, was also the first Secretary General of the OIC. ${ }^{1}$ In terms of government administration, there has been an increasing pattern of Islamic influence in Malaysia's premierships, both in the domestic and international arenas. The events of 9/11 and the invasion of Afghanistan and later Iraq by the Bush administration resulted in Malaysia taking a strong stand against Washington. Malaysia continued to forge close ties with many Muslim countries.

The American "war against terror" launched by the Bush administration was widely interpreted as "war against Islam." This contributed to anti-U.S. sentiments across the globe, including in Southeast Asia. In short, Islamophobia brought Malaysia and international Muslim communities closer. In effect, Islam remained a major factor in Malaysia's close relations with the Muslim world throughout the Mahathir administration. ${ }^{2}$ As a leading Islamic country, Malaysia's Islamic diplomacy was seen as an accommodating tool to respond to international events and promote moderation and world peace.

Just as how Malaysians work together towards the realization of a united and strong country, the international Muslim community could also unite to realize their common goal of creating a prosperous and harmonious world where all countries work together for their mutual benefit and interest. Malaysia's foreign policy is also geared towards transforming Malaysia into a modern, dynamic and progressive Muslim country.

\section{B. DISCUSSION}

Abdullah Badawi became the country's fifth Prime Minister at a very significant period, when the development of technology, globalization, created stronger demands for a more open and transparent economy and business environment. ${ }^{3}$ Since the advance of globalization, national image and reputation abroad have become ever more critical assets and a very important component for nations in the modern world. The Islamic public diplomacy that Abdullah used was to reverse the anti-Western image created during the

\footnotetext{
${ }^{1}$ Mohamad Abu Bakar. Islam in Malaysia's Foreign Policy, Hamdard Islamicus. In. M. Azhari Karin et. al (Ed.). Malaysian Foriegn Policy. Issues and Perspectives, page.77-88. Kuala Lumpur: National Institute of Public Administration. 1990.

2 Khadijah Md. Khalid, 2004, Malaysia's Growing Economic Relations with the Muslim World. Kyoto Review of Southeast Asia, Retrieved from http://kyotoreview.org/issue-5/malaysias-growing-economic-relations-withthe-muslim-world/ [14 April 2018].

3 Mohammed Nasrudin, 2005, A Brief Look at the Malaysian Prime Ministers' Leadership Styles. Journal of Administrative Science, 2(1), Page. 39-54.
} 
Mahathir era and promote a more liberal image of Malaysia as an Islamic centric nation, for globalization has increasingly proven that Malaysia needs Western support and it is the responsibility of any good government to safeguard the nation's reputation through public diplomacy.

Abdullah's philosophy was to make Islam a more holistic tool to include spiritual development in addition to Mahathir's focus on economic development. Rising to play a more extensive role in politics, economy and society, both in the domestic and international arenas, Abdullah's leadership was increasingly making effective use of public diplomacy tools to project an image of Civilized Islam (Progressive Islam) or also known as Islam Hadhari in Malaysia.

The concept of Islam Hadhari was formulated with the intention of ensuring peace and stability in the region, while being able to empower Muslims to face the global challenges of the day. ${ }^{4}$ It explains Malaysia's main diplomatic reform strategies during Abdullah premiership that included the concept of Islamic values and teaching in the government administration.

The development of the internet and increased communication between people from different countries made public diplomacy at the domestic and international level critical, for what happens at the domestic level can become an international issue. Therefore Abdullah's Islam Hadhari sought to develop a positive image of Malaysia not only locally but also in global equivalence.

To formulate national policies and brand them requires the involvement of the public as part of the government's decision making and public diplomacy strategy. ${ }^{5}$ In the development of Islam Hadhari Abdullah, unlike his predecessor, invited public contribution to develop the ideas and take joint ownership, as part of his reforms towads the government policies.

The target audiences of Abdullah's Islam Hadhari included, not only citizens of the state but also foreign investors, tourists, consumers, students, NGOs, entrepreneurs, trading partners, the media, other governments, donors, and multilateral agencies. Abdullah's public diplomacy formed part of a broader involvement of society in both local and international relations. This concept formed a fundamental part of his public

\footnotetext{
${ }^{4}$ Ibid.

5 (Melissen, J (Ed.), 2005, The New Public Diplomacy: Soft Power in International Relations. United Kingdom: Palgrave Macmillan.
} 
diplomacy choice for both domestic and internationally field, in which it must not become disconnected.

Islam Hadhari was motivated for domestic and international consumption. At the domestic level, Islam Hadhari was adopted by Abdullah's administration as the political tool to win Muslim hearts. ${ }^{6}$ Islamic resurgence, that took root during the time of Mahathir, became a reality in Malaysia. People became increasingly more Islamic with the development of knowledge and Islamic teaching. With easy access to information and the multimedia, Muslims in Malaysia became more aware and knowledgeable of the tenets of Islam. Muslims became more inclined to piety, Islamic education and values. Also to counter the re-emergence of the opposition Islamic party, PAS, the ruling government was pressurised to greater Islamic orientation in politics, with a wider adoption of Islam by the ruling party, UMNO and its leadership. ${ }^{7}$

Islam Hadhari were introduce in order to established environment for the development of people capable of dealing with Islamic source, the Quran (the Word of God) and the Sunnah (teachings and attributes of Prophet Muhammad) which is the are the guideline for Muslims to the right path of God and lead Muslims to comprehensive and peaceful life according to facts and reality based on rational explanation.

The aims to bring back the glory of Islamic civilization as what left of the glory of Islam is merely legacies of its past model of many great scholars, such as Ibn Sina, Ibn Rushdi, Al Farabi and Ibn Khaldun. They were ahead of everyone else in their particular fields as they expert in. Their contributions to the modern and Islamic civilization, which are very beneficial for humankind and human civilizations. This would upgrade the status of Islam, the people and earn the respect from other strong in economy, politics and other scientific and technological advancement.

A motivation for Abdullah to promote Islam Hadhari on the international level as part of his public diplomacy was to counter international perception that label Islam as outdated, backward prone to encourage fundamentalism and underdevelopment. The challenge faced by Islam contributed significantly to this new approach as development and modernization purposed.

Part of Abdullah's international public diplomacy was to overcome the negative perceptions towards Islam being associated with extremism, to achieve the intangible

\footnotetext{
6 interview Syed Hamid Albar, 14 Dec 2015, SPAD Headquarters, Kuala Lumpur

7 Ibid
} 
nature of increased trust and improved relationships with its audience, when Muslims were associated with violence, and Islamophobia made anti-Muslim sentiments worse. Abdullah's public diplomacy challenge was when most western countries did not respect Muslim societies. As a major population of Malaysia are Muslims, it has been important to fix this sentiment towards Muslim for the growth of the nation, and for the Malaysian citizen to gain recognition and respect from international communities, especially non-Muslim communities. It has been a major challenge for Malaysia's international public diplomacy when the perception that relate Islam, Muslims and acts of terrorism, extremism and other negative element as portray by the international media in the movie such as Fitna ${ }^{8}$ and the portrayals of Muslim Prophet Muhammad in the violence movement and activity by the anti-Islam people that have sparked controversy and offended many Muslims. ${ }^{9}$

\section{Role of Islam in Domestic Politics}

The concept of public diplomacy not only applicable in the international sphere, but it is also becoming more relevant to domestic policies ${ }^{10}$ for both domains are increasingly interconnected $^{11}$ in a globalizing world where national issues are quickly carried into the international scene, affecting both the state and its people. Therefore public diplomacy in Malaysia's domestic politics continues to remain an important element.

Abdullah Badawi continued on Mahathir's legacy, in carrying out Islamic elements in the administration. He officially introduced Islam Hadhari as a mainstream Malaysian public policy decision making process and as the hallmark of his administration.

Islam Hadhari as promoted by Abdullah as a public diplomacy vehicle has been carried out to achieve two basic goals in his administrations. First, the concept helped to situate the role of Islam and the Muslim community, ummah, in the context of the development of the Malaysian economy. ${ }^{12}$ Muslims would be encouraged to seek

8 Van Zoonen, L. Hirzalla, F \& Müller, F. Fitna: The Video Battle 2010. Retrieved from http://www.lboro.ac.uk/media/wwwlboroacuk/content/socialsciences/downloads/BJoS\%20Fitna\%20Van\%20 Zoonen,\%20Muller,\%20Hirzalla.pdf [15 April 2015].

${ }^{9}$ http://www.nydailynews.com/news/politics/9-controversial-portrayals-mohammed-spurred-backlash-article1.2068915 [15 April 2015].

${ }^{10}$ Gonesh, A \& Melissen, J. Public diplomacy: Improving practice. Netherlands Institute of International Relations" Clingendael". 2005.

${ }^{11}$ Cull, Nicholas J, 2009, "Designing Out the Mess: A Historically Literate Approach to Re-Booting U.S. Public Diplomacy." Public Diplomacy Magazine: 14

12 Khadijah Md. Khalid, 2007, Voting for change: Islam and Personalized Politics in the 2004 General Elections, In. Edmund, T. G (Ed.), 2007, Politics in Malaysia: The Malay Dimension, Page .138-158. New York: Routledge Taylor and Francis Group. 
knowledge, namely in science and technology, in order to help improve the socioeconomic standing of the community ummah as well as generate economic growth. In order to achieve these aims, Islam Hadhari would help bridge differences between Muslims and non-Muslims, thus serving to overcome racial polarization that remained a serious problem in the country. ${ }^{13}$

\section{a) UMNO and Islam}

As Islam was used as a major reforms in the political strategy in Malaysia, it was a successful decision taken by Abdullah to promote Islam Hadhari. Islam Hadhari was increasingly becoming an important manifesto for elections and became an important campaign issue by the Barisan Nasional (BN) coalition. That was one of the glory days for BN as they achieved landslide victory in the 2004 election where the Barisan Nasional ruling coalition won $64 \%$ of the votes and $90 \%$ of the parliamentary seats, ${ }^{14}$ compared to PAS that only won 7 seats.

The Government used public diplomacy through Islam Hadhari to influence the voters. Islam was a strategic influence, as PAS tried to capitalize on its Islamic credentials to influence the people of the state. Abdullah through UMNO countered this by introducing Islam Hadhari as their own Islamic vision for Malaysia. It not only won the heart of Muslims but also the non-Muslim trust for BN to govern. BN succeeded in linking PAS to radical Islam and itself to "moderate", progressive Islam. ${ }^{15}$ PAS had clearly mistaken on the type of Islam desired by its Malay-Muslim voters at that moment, ${ }^{16}$ the concept of Islamic State promoted by PAS was rejected, even by Muslim voters. Abdullah utilized the public diplomacy approach by asking Malaysian voters to give him a bigger mandate so that he could push forward his agenda of moderate Islam and combat corruption and inefficiency. The results showed a shift from fundamentalist Islam to moderate Islam through the elections result. He did carry out the promise at the beginning of his administrations.

\footnotetext{
13 Ibid.

14 Political Tsunami? A Threat to the Prime Minister, 2008, The Economist. Kuala Lumpur, Retrieved from http://www.economist.com/node/10833119 [15 April 2018].

15 Ibid.

16 Humphreys, A. Malaysia's Post-9/11 Security Strategy: Winning" Hearts and Minds" or Legitimising the Political Status Quo. Kajian Malaysia, 28(1), 21-52. 2010.
} 


\section{b) Promoting Islam Hadhari as Public Diplomacy}

Public diplomacy may involve different approaches in promoting the idea of Islam Hadhari in the region. In order to enlighten and spread the Islam Hadhari philosophy, the government, via the Information Ministry's Special Affairs Department, launched a fiveyear information campaign in the wake of the elections. Led by a 20-man panel made up of religious leaders, journalists, academics, lawyers and psychologists, the campaign involved 600 speakers disseminating information on the concept to the public through various forums. ${ }^{17}$

The Federal Government's sponsored think tank institutions and networks, such as Institut Kesepahaman Islam Malaysia (the Institute of Thought of Islam, Malaysia), Jabatan Kemajuan Islam Malaysia (the Office of Islamic Progress, Malaysia), Yayasan Dakwah Islamiyah Malaysia (the Foundation of Islamic Propagation, Malaysia), and Institut Islam Hadhari (the Institute of Islam Hadhari) provided information, news, and articles promoting Islam Hadhari as a government and public agenda, as public diplomacy is one of the approach in influencing people about government policy choices, and it is important for the government to give accurate knowledge and information regarding the implementation of the Islam Hadhari concept in the region.

The effort in promoting Islam Hadhari can be further seen through different effort carried by government sponsored think tanks, and in the educational institutions. At the university level, students are required to take Islamic Civilization and Asian Civilization (TITAS) one of the principal components of Islam Hadhari. It is compulsory for all students to sit for TITAS paper, and this requirement is applied to both Muslim and nonMuslim students. ${ }^{18}$

In line with promoting public diplomacy through Islam Hadhari, the Institute of Islam Hadhari that were established in the Universiti Kebangsaan Malaysia (UKM), plays a significant role in promoting Islam Hadhari. It conducts research, academic programs, seminars, workshops, discourses and forums, publications, consultations and cooperation networks among the national and international audience.

\footnotetext{
17 Ibid

18 Nazri Muslim, Abdul Latif Samian \& Nur Hafilah Musa. Implementation of Islamic Civilization and Asian Civilization Course: Experience in National University of Malaysia and Private Higher Education Institutions towards Consolidating the Element of Science and Technology. Asian Social Science, 11( 22), 116. 2015
} 


\section{c) Other Instruments of Islamic Public Diplomacy}

Even as the Abdullah administration introduced sophisticated and even abstract ideas of Islam Hadhari, it also continued the impact and influence of the institutions created by the Mahathir administration, such as the development of the Islamic legal system, the International Islamic University of Malaysia and other Islamic educational institutions, and Islamic financial institutions

\section{d) Misconception of Islam Hadhari}

Before Islam Hadhari were introduce to the people the former foreign minister Syed Hamid Albar, personally advice Abdullah, to use another term for this concept manhaj (approach) Islam Hadahri as to avoid confusions among the audiences of the state. But he still carry out with the branding and the term of Islam Hadhari. ${ }^{19}$ When Islam Hadhari were adopted into Malaysian development program, Malaysia citizen have responded to it in various ways.

The first response views Islam Hadhari as a political strategy to win over Muslim hearts especially among the Malay who are currently moving towards adopting Islam in all their daily activities. The fact that Islam Hadhari is used as political strategy is something we can't deny. With the resurgence of PAS, Islam Hadhari was consider as one way out to influence the people of the state in order to sustain BN influence and power in governing Malaysia. With the islamization process that take place in Malaysia, Muslim seems to be more aware of their Islamic identity and need for piety. One result of Islamic reawakening is seen a rises of Islamic movement and groups. This obligation is clearly seen in their dress code, and commitment to their daily prayers, fasting, pilgrimage, zakat and other act of worship.

Muslim as well as non-Muslim who are critical of Malaysian politics, look at the adoption of Islam Hadhari with skepticism. PAS also commenters of Islam Hadhari, make joke of it's by saying that Hadhari means "had hari"it is limited to certain days. ${ }^{20}$ The PAS leader, $\mathrm{Hj}$ Abdul Hadi also wrote a book in critics towards the implementation of Islam Hadhari in the region, namely Hadharah Islamiyyah Bukan Islam Hadhari : Satu Ulasan dan Penilaian. For some people they Islam Hadhari is seen as liberalization of Islam

\footnotetext{
${ }^{19}$ Interview Syed Hamid Albar

20 Penyokong Pas, 2009, Islam Ada "Had", Islam Ada "Hari". Retrieved from https://penyokongpas.wordpress.com/tag/islam-hadhari/ [10 January 2015].
} 
especially on issues such as gender, social and political issues. The involvement of women in the civil society were seen as the negative element in Islam Hadhari. As such some conservative Muslim reject the socialization effect of Islam Hadhari. They consider Islam Hadhari a liberal sections of Islam.

The adoptions of Islam Hadhari views it as a threat to religious freedom. Many nonMuslim feel that by adopting Islam Hadhari, Malay Muslims are moving towards more Islamic oriented activities. There is danger in this. Islam is seen as a religion associated with intolerance, extremisms and radicalisms. Furthermore, with the expression of islamophobia sentiments in the western media, it is not impossible for non-Muslim citizen to share their sentiments and fight for their rights to be given wider freedom to practice their religious activities. This evident in some political speeches of an opposition party that questioned the relevance of Islam Hadhari in a country it claimed to be secular state.

\section{e) Decline of Islam Hadhari}

Joseph Liow argues that what is actually innovative about Islam Hadhari is the form of the idea, rather than its actual content. Liow contends that Abdullah had succeeded in expressing the state's well-entrenched ideology in "readily identifiable and catchy Islamic terminology." 21 The adoption of Islam Hadhari shows that with the declaration and adoption of Islam Hadhari at UMNO national congress in 2004 became the dominant public diplomacy approach. However, Malaysia's citizen have yet to respond favourability to the ongoing development where Islam Hadhari that adopted by Abdullah as a core value of his leadership.

Islam Hadhari as a core value to upgrade the Muslim ummah in Malaysia has backfired on Abdullah leadership. Although Islam Hadhari has the potential core value for development in Malaysia, yet Malaysian citizen have problems in comprehending the concept. More importantly, some among the political elite who are supposed to be propagators and key movers of Malaysian development could not gain the strong support it needs, lack of support for the government at that time which was manifested in the last general elections is due to various factors. However, Islam Hadhari could be one of them in the sense that many Muslim citizen do not understand the concept, and it has been capitalized by other political parties, especially PAS. On the other hand, non-Muslim who do not understood the concept have been influence by the domestic and international

${ }^{21}$ Liow, J, 2005, The politics behind Malaysia's eleventh general election, Asian Survey, 45 (6), Page. 907930. 
media which intentionally tarnished the image of Islam. As a result, many non-Muslim citizen opted to choose an alternative.

Upon the adoption of Islam Hadhari in Malaysia's administration as the core value of development, the international media such as BBC and CNN have broadcast a negative image of Malaysia, especially on the issues of freedom of religion and human right issues that relate to ISA. They keep characterizing Malaysia as a racialist and conservative Muslim country when commenting upon issues of human rights and freedom. As a result, when a more Islamic orientation politics in Malaysia become obvious, the international concern over Malaysian politics take significant leap.

The domestic politics of Malaysia under Abdullah's Leadership has become more unstable following former Prime Minister continued criticism of Abdullah leadership as weak and unstable. After 12 general election on 2008, Abdullah has been challenged to resign from the premiership. On the other hand, with the split of the political elite over the nomination of candidates for the last elections from amongst the political leaders, the disunity of the political elite has been more apparent. As a result, with the misapprehensions over the concept of Islam Hadhari on the one hand and the split in the political elite on the other, Abdullah's leadership is coming to the end.

The concept of Islam Hadhari not properly socialized and made known to all Malaysians regardless of race, religion an economic and social status. The term public diplomacy is even used for publicity work aimed at domestic audiences. Islam Hadhari as a modern approach to Islamic social political development needs more efforts at socialization of its principle. The socialization may be done through various strategies depending upon the target group such as domestic and international audience, Muslim and non-Muslim. The most important socialization aspect of Islam Hadhari is through the adoption and implementation of its concept among the political leadership and government administration.

However, other strategic methods for the socialization of Islam Hadhari are equally important to be formulated and adopted for the various level of audience. It can be socialized through formal and informal means. Formal means include formal educations, seminars, workshops, and training session among the targeted groups. The later may include socialization through personal, moral and good behaviour influence which could be affective through personal interaction within organization and the community. There is 
much work ahead for the government and Muslim in the country if Islam Hadhari is to be understood and accepted by Muslims as well as non- Muslim.

\section{ROLES OF ISLAM IN THE GLOBAL ENVIRONMENT}

The elements of Islam Hadhari are very general and as such could be applied in all aspect of public diplomacy approach. Through public diplomacy, Malaysia's government promotes its image internationally. Abdullah took every opportunity he had at the international level to promote the ideas of Islam Hadhari that he believed Muslim countries should practice. During his official visit to Australia from $6^{\text {th }}$ to $9^{\text {th }}$ April 2005 , the first by a Malaysian Prime Minister after twenty one years, Abdullah expounded on "Islam Hadhari In A Multi-Racial Society" to the Asian Society of Australia in Sydney. ${ }^{22}$ He spoke about it again when he addressed the Bertelsmann Foundation in Berlin in May with a speech titled "Islam, International Peace and Security".23 It was a passionate belief that he carried with him to all the international events that he attended and he took every opportunity to explain its meaning and its reasonableness. By opening up and stepping into the global arena to promote the idea of Islam Hadhari, Malaysia gained international support by playing an active role in the field of public diplomacy. It is mainly associated with its international aspect, directed towards foreign publics and conducted abroad.

\section{a) Model of Muslim State}

In addition to Islam Hadhari playing a significant role in domestic public diplomacy, it was also widely promoted to international audiences, reaching out to Muslim and non-Muslim audiences. In a sense, the concept was being promoted by government as the means to develop a model Muslim state. Islam Hadhari was portrayed as a model for the development of Muslims, at the secular and spiritual level, both nationally and internationally. It also served to counter the extremist ideologies of al-Qaeda and similar organizations.

A primary function of Islam Hadhari was to set Malaysia as a model Muslim nation and a leader of the Islamic world. When Abdullah presided over the OIC, it gave him the opportunity to promote Islam Hadhari more aggressively to other Muslim nations. While

\footnotetext{
22 Abdullah Badawi, 2005, Islam Hadhari in a multi-racial society. Speech, Asia Society of Australia, Sydney. $8^{\text {th }}$ April 2005. Retrieved from: http://www.pmo.gov.my/ucapan/? $m=p \& p=p a k l a h \& i d=2937$ [15 July 2015].

23 Abdullah Badawi, 2005, The Bertelsmann Foundation Berlin -"Islam, International Peace and Security", speech at Berlin, Germany. 18 ${ }^{\text {th }}$ May 2005. Retrieved from http://www.pmo.gov.my/ucapan/?m=p\&p=paklah\&id=2950 [15 July 2015].
} 
support for Islam Hadhari was often times mere rhetoric by OIC member, it was incorporated into the Makkah Declaration as part of the OIC 2005 summit. ${ }^{24}$ It also allowed the Prime Minister to internationalize UMNO's religious credentials. ${ }^{25}$

Although Abdullah accepted that Islam Hadhari did not provide a comprehensive key to the development of Islamic states, Abdullah emphasized that Malaysia nonetheless provided an insight into how to successfully build a progressive and modern Muslim nation. ${ }^{26}$ Prime Minister Manmohan Singh of India stated that his country shared Malaysia's view of Islam as a "civilizational force" and described Islam Hadhari as "timely and necessary."27 In the years that followed this statement, however, there are only a few examples of countries indicating an interest in Islam Hadhari, let alone actually implementing it. In 2006, Brunei also expressed an interest in the Islam Hadhari approach. ${ }^{28}$ Thus it shows that the public diplomacy approach that were used did achieve to some extent their goals in promoting the state and national branding. It will be safe to assume if national leaders are willing to consider the implementation of Islam Hadhari, the public of those states that did not profess to apply the principles would nevertheless support the ideas. Anyway the social media and the increasing mobility of global citizens have blurred distinctions between domestic and international audiences.

\section{b) War on Terrors}

The post-September 11 world increased the international stakes for a moderate Islam and Islam Hadhari provided the response. As the event was assumed to be related to Islam. Islam Hadhari proved to be an attempt to recover Islam's image and, in Abdullah's words:

"To extricate the Islamic world from this crisis and to help the process of rehabilitating ourselves to restore Islam's past glory. "29

\footnotetext{
24 Zubaidah Abu Bakar, Civilizational Islam' Approach Accepted, New Straits Times. Kuala Lumpur. 9 December 2005.

25 Khoo Boo Teik, 2004,'The house of the rising sons: What they didn't debate at the UMNO general assembly', Aliran Monthly, 2004, http://www.aliran.com/oldsite/monthly/2004b/9c.html [5 April 2018].

${ }^{26}$ Islam Online. Malaysian PM Takes Islam Hadhari' to India . Islam Online Net. 22 December 2004. Retrieved from http://www.islamonline.net/English/News/200412/22/article03.shtml [10 April 2018].

${ }^{27}$ Hindustan Times, 2004, Islam as a civilisational force, India shares Malaysia's vision', Hindustan Times. 22 December.

28 News Agencies, 2006, Brunei keen on Malaysia's 'Islam Hadhari' Concept, Organisation of Asia-Pacific News Agencies. 5 July 2006.

${ }^{29}$ Abdullah Badawi, 'UMNO's 57th Annual General Assembly'. Speech, UMNO 57th General Assembly. Kuala Lumpur. 15 November 2006.
} 
In terms of the wider War on Terror, the concept has had more, albeit limited, success. During a working visit to Malaysia in 2005, Robert Zoellick, now US Deputy Secretary of State, was briefed on Islam Hadhari. Of particular interest to Zoellick was the concept's applicability to the situation in Iraq and whether the Malaysian government could use its experience to help. US image builder Karen Hughes reaffirmed this during a visit to Malaysia later that year. Hughes stated that the BN model provided an "outstanding" model of governance for Iraq. Hughes secured a pledge from Malaysia to spread Islam Hadhari to help fight terrorism in Iraq, stating, "Islam Hadhari has a powerful message of inclusion and acceptance." ${ }^{\prime 30}$

Other Middle Eastern countries have reportedly also invited Malaysia to describe the concept. Ultimately, Islam Hadhari signals not just a philosophical attempt to combat extremism within the Muslim world, but provides to the rest of the world, the West in particular, an image of Islam that counters the rhetoric of extremists. In developing and deciding upon Abdullah's public diplomacy activities, he denies that, it is not an approach to pacify the West. It is neither an approach to apologise for the perceived Islamic threat, nor an approach to seek approval from the non-Muslims for a more friendly and gentle image of Islam. It is an approach that seeks to make Muslims understand that progress is enjoined by Islam". ${ }^{31}$

Islam Hadhari has become more than a mere philosophy to be emulated by other Muslim countries. For example, Abdullah later stated that there was a noticeable difference in the tone and views of non-Muslim communities overseas after 9/11 when compared to their views after the Islam Hadhari concept was explained to them. Foreign Minister Syed Hamid Albar also noted that several European countries saw Islam Hadhari as a useful "platform" to foster more effective relations. Islam Hadhari ultimately allows Malaysia to position itself as a model Muslim society, one which counters the view prevalent in the West of Islam as radical and backward.

In regards to the "hearts and minds" component, the government has continued its anti-extremist stance at the political level. Marking a shift in policy, though, the rhetoric has been revamped and repackaged into Prime Minister Abdullah Ahmad Badawi's Islam Hadhari philosophy. In fact, in an attempt to "rehabilitate" Islam in the eyes of the global

\footnotetext{
30 Leslie Lau, Malaysia the Way to go for Iraq, Says US Image Czar, The Straits Times. 26 October 2005.

31 Abdullah Badawi, 2005, Islam Hadhari in a multi-racial society, Speech, Asia Society of Australia, Sydney. $8^{\text {th }}$ April 2005. Retrieved from http://www.pmo.gov.my/ucapan/?m=p\&p =paklah\&id=2937 [15 April 2018].
} 
audience, Malaysia has attempted to export Islam Hadhari to other countries, framing it as a "moderate" approach to development and a solution to extremism. The exportation of this model has thus far met with minimal success. ${ }^{32}$

\section{CONCLUSION}

Abdullah took the office as the fifth Malaysia Prime Minister at a most significant period of the state. With the increasing pressures of globalization, stronger demands for a more open and transparent government, Abdullah's rise to the top was timely. Using the Islamic sentiment brought forward from the previous premiership, Abdullah carried out the concept of Islam Hadahri. The implantation of Islam Hadhari has been an important public diplomacy approach used by the Abdullah administrations. The approach has not only been important for domestic consumptions but also formed a part of Malaysia's foreign policy.

However, other strategic methods for the socialization of Islam Hadhari are equally important to be formulated and adopted for the various level of audiences, which are also important elements in the public diplomacy process. The means that are used by the government to promote Islam Hadahri via the public diplomacy approach included formal educations, seminars, workshops, and training session for national and international audiences. The latter may include socialization through personal, moral and good behaviour influence which could be effective through personal interaction within organizations and the community. There are a number of government bodies that were involved in promoting this approach. There is also much work ahead for the government to give accurate information and knowledge about Islam Hadahri. But like some other government policies that look good on paper but is not effectively implemented, Islam Hadhari is also trapped in the same fate. The Islam Hadhari approach was initiated with noble aims and objectives. However the poor implementation and misconception of the approach itself led to the declining influence of the Islam Hadhari approach.

Even though Islamic values are the basis of its culture and civilization, some people may assume the values of Islam are no longer relevant and they are against modernized western values. In order to counter the misconceptions, the Malaysian government has increased their public diplomacy about Malaysia's stand and position in upholding Islamic

\footnotetext{
${ }^{32}$ Ibid
} 
values in their administrations in an attempt to respond to the negative image of Islam and Muslims across the world and to prove that development and progress are part of Islam. This public diplomacy approach has been to convey the message that Islam does not keep Muslims in ignorance, intolerance and poverty. There is no place for negative thought and practice in Islam.

Constructivism theory states that norms and values determine the decision making policies and policy options of the state. Abdullah's inclusion of Islamic values and principles into his domestic and international relations and public diplomacy, similar to Mahathir, are based on constructivist principles. Abdullah was greatly influenced by his religious background and education. The idea of Islam Hadhari was formulated with the intention of ensuring peace and stability in the region, while being able to empower Muslims to face the global challenges of the day. In the constructivist idea, role prescriptions are shared norms and expectations which form the social structure of the international system and the structural source of their national roles.

\section{BIBLIOGRAPHY}

9 controversial portrayals of Muhammad - NY Daily News. 2015. New York Daily News. New York. Retrieved from http://www.nydailynews.com/news/politics/9controversial-portrayals-mohammed-spurred-backlash-article-1.2068915 [15 April 2015].

Abdullah Badawi. 2005. Islam Hadhari in a multi-racial society. Speech, Asia Society of Australia, Sydney. $8^{\text {th }}$ April 2005. Retrieved from http://www.pmo.gov.my/ucapan/?m=p\&p=paklah\&id=2937 [15 April 2018].

Abdullah Badawi, 2006 'UMNO's 57th Annual General Assembly'. Speech, UMNO 57th General Assembly. Kuala Lumpur. 15 November.

Abdullah Badawi. The Bertelsmann Foundation Berlin -"Islam, International Peace and Security", speech at Berlin, Germany. 18 $18^{\text {th }}$ May 2005. Retrieved from http://www.pmo.gov.my/ucapan/?m=p\&p=paklah\&id=2950 [15 July 2015].

Cull, N. J. 2009. Designing Out the Mess: A Historically Literate Approach to Re-Booting US Public Diplomacy. Public Diplomacy Magazine, 14.

Gonesh, A \& Melissen, J. 2005. Public diplomacy: Improving practice. Netherlands Institute of International Relations" Clingendael". 
Hindustan Times. 2004. Islam as a civilisational force, India shares Malaysia's vision', Hindustan Times. 22 December.

Humphreys, A. 2010. Malaysia's Post-9/11 Security Strategy: Winning" Hearts and Minds" or Legitimising the Political Status Quo. Kajian Malaysia, 28(1), 21-52.

Islam Online. 2004. Malaysian PM Takes Islam Hadhari' to India .Islam Online Net. December $22 . \quad$ Retrieved from http://www.islamonline.net/English/News/200412/22/article03.shtml $\quad\left[\begin{array}{ll}10 & \text { April }\end{array}\right.$ 2015].

Khadijah Md. Khalid. 2004. Malaysia's Growing Economic Relations with the Muslim World. Kyoto Review of Southeast Asia, Retrieved from http://kyotoreview.org/issue5/malaysias-growing-economic-relations-with-the-muslim-world/ [14 April 2018].

Khadijah Md. Khalid. 2007. Voting for change: Islam and Personalized Politics in the 2004 General Elections. In. Edmund, T. G (Ed.). Politics in Malaysia: The Malay Dimension, p.138-158. New York: Routledge Taylor and Francis Group.

Khoo Boo Teik. 2004. The house of the rising sons: What they didn't debate at the UMNO general assembly. Aliran Monthly. Retrieved from http://www.aliran.com/oldsite/monthly/2004b/9c.html. [5 April 2018].

Leslie Lau. 2005. Malaysia the Way to go for Iraq, Says US Image Czar. The Straits Times. October 26.

Liow, J. 2005. The politics behind Malaysia's eleventh general election. Asian Survey, 45(6), 907-930.

Melissen, J (Ed.). 2005. The New Public Diplomacy: Soft Power in International Relations. United Kingdom: Palgrave Macmillan.

Mohamad Abu Bakar. 1990. Islam in Malaysia's Foreign Policy, Hamdard Islamicus. In. M. Azhari Karin et. al (Ed.). Malaysian Foriegn Policy. Issues and Perspectives, p.7788. Kuala Lumpur: National Institute of Public Administration.

Mohammed Nasrudin. 2005. A Brief Look at the Malaysian Prime Ministers' Leadership Styles. Journal of Administrative Science, 2(1), 39-54.

Nazri Muslim, Abdul Latif Samian \& Nur Hafilah Musa. 2015. Implementation of Islamic Civilization and Asian Civilization Course: Experience in National University of Malaysia and Private Higher Education Institutions towards Consolidating the Element of Science and Technology. Asian Social Science, 11(22), 116.

News Agencies. 2006. Brunei keen on Malaysia's 'Islam Hadhari' Concept. Organisation of Asia-Pacific News Agencies. 5 July. 
Penyokong Pas. 2009. Islam Ada "Had", Islam Ada "Hari". Retrieved from https://penyokongpas.wordpress.com/tag/islam-hadhari/ [10 January 2015].

Political Tsunami? A Threat to the Prime Minister. 2008. The Economist. Kuala Lumpur. Retrieved from http://www.economist.com/node/10833119 [15 April 2018].

Syed Hamid Albar. 2015. Interview. 14 Dec 2015. SPAD Headquarters, Kuala Lumpur.

Van Zoonen, L. Hirzalla, F \& Müller, F. 2010. Fitna: The Video Battle. Retrieved from http://www.lboro.ac.uk/media/wwwlboroacuk/content/socialsciences/ downloads/BJoS\%20Fitna\%20Van\%20Zoonen,\%20Muller,\%20Hirzalla.pdf April 2018].

Zubaidah Abu Bakar, 2005, December 9, Civilizational Islam' Approach Accepted. New Straits Times. Kuala Lumpur. 